\title{
The association between denture care and oral hygiene habits, oral hygiene knowledge and periodontal status of geriatric patients wearing removable partial dentures
}

\section{Purpose}

This study aims to evaluate the association of the denture care with oral hygiene habits, knowledge and periodontal status geriatric patients wearing removable partial denture (RPD) and to compare the relationship between denture cleaning and tooth brushing frequency.

\section{Patients and Methods}

In total, 553 participants wearing RPD for at least 6 months and aged 65-86 years were asked to complete a questionnaire following the clinical examination. Chisquare analysis and Fisher's exact test utilized to analyze the data.

\section{Results}

A significant relationship was found between the frequency of smoking, denture age, overnight denture wearing, denture stomatitis and denture cleaning $(p<0.05)$. $54.10 \%$ of the participants reporting that they did not have information about denture care had poor denture cleaning. Among patients brushing once per day, $26.34 \%$ had a good level of denture cleaning; whereas, this was $39.40 \%$ for those brushing three times in a day.

\section{Conclusion}

The type of advice (verbal or written) and oral hygiene habits demonstrated a more significant impact on the cleaning level of dentures than the socioeconomic level, smoking, overnight use, denture age. The success of denture maintenance might depend on the patients' knowledge of denture care and hygiene habits and geriatric patients' motivation.

Keywords: Geriatrics; knowledge; oral hygiene; removable dentures; toothbrushing

\section{Introduction}

Edentulousness is a multi-factorial phenomenon that has an impact on the quality of life of individuals (1-4). The maintenance of the continuity of the mastication system and elimination of aesthetic and phonetic problems require a successful restoration and rehabilitation. A removable partial denture (RPD) is intended for partially edentulous patients who cannot have a bridge or an implant due to lack of required teeth to serve as bridge support, high cost and so forth and who want to have replacement teeth for function. Out of various treatment strategies for partial edentulism such as implant- and tooth-supported fixed prostheses, a well-designed partial removable dental prosthesis (PRDP) is still one of the mostly performed treatment modalities $(5,6)$ fulfilling the needs of millions of individuals worldwide (7-9) or applied for aesthetic reasons. Regular oral and denture hygiene habits play important role in maintenance of oral health and long- term use of removable prostheses (3-10).

\author{
Zeynep Turgut Cankaya' ${ }^{1}$, \\ Aysegul Yurdakos ${ }^{2}$ (D), \\ Pelin Gokalp Kalabay ${ }^{3}$
}

ORCID IDs of the authors: Z.T.C. 0000-0002-9960-5290;
A.Y. 0000-0002-8706-6445; P.G.K. 0000-0002-1263-6183
'University of Gazi, Faculty of Dentistry, Department of
Periodontology, Ankara, Turkey
2Okmeydanı Oral and Dental Health Hospital, Istanbul,
Turkey
'Private Periodontist, Istanbul, Turkey

Corresponding Author: Zeynep Turgut Cankaya

E-mail: zeynepturgut@gazi.edu.tr

Received: 3 May, 2019 Revised: 18 Jun, 2019 Accepted: 12 Jully, 2019

DOI: $10.26650 /$ eor.20200048 
The awareness and motivation of RPD wearers to maintain a high level of hygiene of residual teeth are extremely important to maintain the health and integrity of teeth and periodontal tissues (11).

A great number of geriatric patients need dental care including RPD. Researches have shown that older people do not clean their dentures properly and do not acquire adequate oral hygiene habits (12-16) due to a number of factors such as social status, age, education, systemic diseases, and smoking (12-15). Also lack of information about the maintenance of oral health and periodic recalls play an essential role in above mentioned situation.

Previous studies have shown a correlation between RPDs and increased risk of periodontal diseases $(17,18)$. Therefore, proper denture use and care constitutes important component not only for functional and aesthetic reasons, but also for the health of the supporting periodontal tissues and appropriate maintenance of the denture itself for RPD wearers (19). Akaltan et al. concluded that adequate oral hygiene and regular systemic controls can improve periodontal health of patients with RPD (20). The purpose of this study is to determine the relationship between smoking, denture age, denture stomatitis, overnight denture wearing habits, knowledge of denture hygiene maintenance, and oral hygiene habits with denture cleaning among the geriatric popula- tion using RPDs. This study also aims to evaluate education and socioeconomic levels of geriatric patients wearing RPD.

\section{Materials and Methods}

In total, 553 partial denture wearers aged 65-86 years (mean age $73 \pm 11$ ) and using prostheses for at least 6 months completed a questionnaire following clinical examination at the Okmeydanı Oral and Dental Health Hospital, Istanbul, Turkey (Figure 1). The protocol of this study was approved by the Okmeydanı Training and Research Hospital Ethics Committee (No.838). This study was performed in compliance with the Declaration of Helsinki.

This study was conducted among geriatric patients applied to the departments of the prosthodontics and periodontology, who already have RPDs. They were informed about the research project and gave their consent in writing.

The subjects were interviewed by experienced single periodontologist using a structured questionnaire which sought to identify gender, educational status, socioeconomic level, smoking habits, frequency of visiting a dentist, denture age, denture stomatitis, overnight denture wearing, denture cleaning frequency, methods and status of ever being informed by dentist about denture hygiene maintenance and oral hygiene habits (PGK).

\section{SECTION 1: For Patients}

1. Smoking status Yes () No ()

2. How long have you been using this denture? 1 year or less ( ) 1-5 years ( ) More than 5 years ( )

3. Do you have any prosthesis-related oral mucosal lesions? Yes ( ) No ()

4. Do you remove your dentures overnight? Yes ( ) No ( )

5. How many times do you clean your dentures daily? Once a day ( ) Twice a day ( ) Three times a day ( ) Over three times a day ( )

6. Have you ever received any instruction from your dentist on how to clean your dentures? Yes () No ()

7. If yes, in what form were the instructions given? Verbal () Written ( ) Both verbal and written ( ) Other ()

8. How many times a day do you brush your teeth? Once a day ( ) Twice a day ( ) Three times a day () Never ()

9. When you brush your teeth, do you have gingival bleeding? Yes ( ) No ( )

10. Have you ever received periodontal treatment? Yes ( ) No ( )

\section{SECTION 2: For Clinicians}

1. Age:

2. Gender:

3. Income: Poor ( ) Low ( ) Middle ( ) High ( )

4. Educational Level: No schooling degree ( ) Lower secondary school ( ) Intermediate secondary School ( ) High school diploma( )

5. Oral hygiene level: Poor ( ) Fair ( ) Good ( )

6. Cleaning of dentures: Poor ( ) Fair ( ) Good ( ) 
The level of prosthesis hygiene was assessed using the Budzt-Jorgensen \& Bertram method (21) by an another experienced single prosthodontist (AK) and ranked in categories, namely, good (no plaque or calculus), fair (plaque or calculus covering less than one-third of the prosthesis), or poor (plaque and calculus covering one-third or more of the prosthesis). Prosthesis types were evaluated on the basis of the previous study where oral mucosal lesions among denture wearers was examined (22), and classified as partially removable dental prosthesis in the maxilla and/or mandible. The denture age of prosthesis was categorized in three groups as less than one year ( $<1$ year), between one and five years (1-5 years), equal to and greater than five years ( $\geq 5$ years). The level of education was classified as illiterate, primary school, secondary school and higher levels; whereas, income level was categorized as poor, low-, middle- and high-income patients. In this study, gingival bleeding was evaluated on the basis of existence of bleeding during tooth brushing. The participants were asked whether they had undergone periodontal treatment before the date of this study.

\section{Statistical analysis}

The data was analyzed with SPSS 20 statistical package (SSS Inc., USA).

Ki-square analysis was applied to reveal the relationship between groups of nominal variable. In case where sufficient volume could not be obtained as per $2 \times 2$ table cells, Fisher's Exact Test was used. Furthermore, RxC tables were verified with Pearson Ki-Square analysis by using Monte Carlo simulation.

The level of significance was identified as 0.05 during interpretation of the results according to which $\mathrm{p}<0.05$ shows meaningful relationship and $\mathrm{p}>0.05$ indicates that any meaningful relationship does not exist.

\section{Results}

In this study, $51.9 \%$ of the subjects were females and $48.1 \%$ was male (Table 1). In terms of level of education, $14.47 \%$

Table 1. Distribution of demographic characteristics of the subjects

\begin{tabular}{llll}
\hline \multirow{2}{*}{ Gender } & & $\mathbf{n}$ & (\%) \\
\cline { 2 - 4 } & Female & 287 & 51.9 \\
\cline { 2 - 4 } & Male & 266 & 48.1 \\
\hline \multirow{2}{*}{ Incomeal } & 553 & 100 \\
\cline { 2 - 4 } & Illiterate & 80 & 14.47 \\
\cline { 2 - 4 } & Primary school & 352 & 63.65 \\
\cline { 2 - 4 } & Secondary school & 56 & 10.13 \\
\cline { 2 - 4 } & Higher & 65 & 11.75 \\
\cline { 2 - 4 } & Potal & 553 & 100 \\
\cline { 2 - 4 } & Loor & 103 & 18.63 \\
\cline { 2 - 4 } & Moderate & 223 & 40.33 \\
\cline { 2 - 4 } & High & 54 & 31.28 \\
\cline { 2 - 4 } & Total & 553 & 100 \\
\hline
\end{tabular}

of participants was illiterate, $63.65 \%$ completed primary school education, $10.13 \%$ had secondary school degree, and $11.75 \%$ held higher education degree (Table 1).

While $40.33 \%$ of the participants stated that they had low income level, $31.28 \%$ and $9.76 \%$ reported they had moderate and high individual income levels respectively (Table 1).

Significant relationship was found between the frequency of smoking habits and denture cleaning $(p<0.05) .50 \%$ of the smoking participants and $31.39 \%$ of the non-smokers had poor denture cleaning (Table 2).

Furthermore, it was found that denture cleaning was directly associated with the period of time participants used their RPDs, overnight use of RPDs and denture stomatitis $(p<0.05)$. Among the participants who reported they had been wearing RPDs less than 1 year, $30.15 \%$ had a good level of denture cleaning; whereas, this rate was found as $20 \%$ among those wearing RPDs more than 5 years. As for the participants removing their RPDs before sleep and continuing to wear RPDs overnight, $34.26 \%$ and $41.24 \%$ had poor denture cleaning respectively. While $41.25 \%$ of patients with denture stomatitis had poor denture cleaning, only $15 \%$ of them had a good level of denture cleaning (Table 2).

In addition, significant relationship was found between the information provided to the wearers about denture care and denture cleaning. Of the participants reported that they did not have information about denture care, $54.10 \%$ had poor denture cleaning and $16.39 \%$ had good denture cleaning (Table 2).

$17.65 \%$ of the participants who stated they only received written instruction on denture care and $27.73 \%$ whom verbal instruction was given had good level of denture cleaning; whereas, $28.24 \%$ of those provided with both verbal and written instruction exhibited good level of denture cleaning (Table 2).

There is also significant relationship between the denture cleaning and the frequency of brushing remaining teeth. $26.34 \%$ of the participants brushing once in a day and $36.90 \%$ of those brushing three times per day had good level of denture cleaning. Among patients with good level of prosthesis hygiene, $97.08 \%$ revealed good level of oral hygiene. On contrary, $92.51 \%$ of the patients with poor level of prosthesis hygiene had poor level of oral hygiene (Table 2).

\section{Discussion}

Hygiene habits, behaviors and knowledge about the denture care of geriatric RPD wearers have been the subject of researches over the years (23-29). Several factors that may be related to the level of denture cleaning were approached by the questionnaire, within the scope of which gender, education, socioeconomic level, smoking habits, denture age, denture stomatitis, overnight denture wearing, frequency of visiting dentist, knowledge about denture hygiene maintenance and oral hygiene habits were examined (29). The present study was undertaken to determine knowledge about the use and care of partial denture among geriatric patients.

In general, the education and socio-economic levels of geriatric patients are associated with their oral health condition. A previous study has demonstrated that the education level and socio-economic stability is positively associated with interest in oral health (30). The present study mainly 
Table 2. Relationship of prosthesis hygiene level with oral hygiene knowledge, habits and periodontal status of subjects

\section{Prosthesis hygiene level}

\begin{tabular}{|c|c|c|c|c|c|c|c|c|c|c|c|}
\hline & & \multirow{2}{*}{\multicolumn{2}{|c|}{ Chi square test }} \\
\hline & & \multicolumn{2}{|c|}{ Good } & \multicolumn{2}{|l|}{ Fair } & \multicolumn{2}{|c|}{ Poor } & \multicolumn{2}{|c|}{ Total } & & \\
\hline & & $\mathbf{n}$ & (\%) & $\mathbf{n}$ & (\%) & $\mathbf{n}$ & (\%) & $\mathbf{n}$ & (\%) & Chi square & $\mathbf{p}$ \\
\hline \multirow[t]{3}{*}{ Smoking status } & Yes & 28 & 17.72 & 51 & 32.28 & 79 & 50.00 & 158 & 100 & \multirow[t]{3}{*}{17.991} & \multirow[t]{3}{*}{0.001} \\
\hline & No & 116 & 29.37 & 155 & 39.24 & 124 & 31.39 & 395 & 100 & & \\
\hline & Total & 144 & 26.04 & 206 & 37.25 & 203 & 36.71 & 553 & 100 & & \\
\hline \multirow[t]{4}{*}{ Denture age } & 1 year or less & 61 & 33.15 & 52 & 28.26 & 71 & 38.59 & 184 & 100 & \multirow[t]{4}{*}{16.92} & \multirow[t]{4}{*}{0.002} \\
\hline & $1-5$ years & 33 & 27.73 & 53 & 44.54 & 33 & 27.73 & 119 & 100 & & \\
\hline & More than 5 years & 50 & 20.00 & 101 & 40.40 & 99 & 39.60 & 25 & 100 & & \\
\hline & Total & 144 & 26.04 & 206 & 37.25 & 203 & 36.71 & 553 & 100 & & \\
\hline \multirow{3}{*}{$\begin{array}{l}\text { Denture stomatitis } \\
\text { (Prosthesis-related } \\
\text { oral mucosal } \\
\text { lesions) }\end{array}$} & Yes & 24 & 15.00 & 70 & 43.75 & 66 & 41.25 & 160 & 100 & \multirow[t]{3}{*}{14.355} & \multirow[t]{3}{*}{0.001} \\
\hline & No & 120 & 30.53 & 136 & 34.61 & 137 & 34.86 & 393 & 100 & & \\
\hline & Total & 144 & 26.04 & 206 & 37.25 & 203 & 36.71 & 553 & 100 & & \\
\hline \multirow{3}{*}{$\begin{array}{l}\text { Overnight denture } \\
\text { wearing }\end{array}$} & Yes & 106 & 29.53 & 130 & 36.21 & 123 & 34.26 & 359 & 100 & \multirow[t]{3}{*}{6.744} & \multirow[t]{3}{*}{0.034} \\
\hline & No & 38 & 19.59 & 76 & 39.18 & 80 & 41.24 & 194 & 100 & & \\
\hline & Total & 144 & 26.04 & 206 & 37.25 & 203 & 36.71 & 553 & 100 & & \\
\hline \multirow{5}{*}{$\begin{array}{l}\text { Frequency of } \\
\text { denture cleaning }\end{array}$} & Once a day & 63 & 31.37 & 73 & 36.87 & 63 & 31.82 & 198 & 100 & 9.42 & 0.151 \\
\hline & Twice a day & 34 & 30.28 & 46 & 42.20 & 30 & 27.52 & 109 & 100 & & \\
\hline & Three times a day & 34 & 25.58 & 40 & 31.01 & 56 & 43.41 & 129 & 100 & & \\
\hline & More than three times & 13 & 21.43 & 22 & 39.29 & 22 & 39.29 & 56 & 100 & & \\
\hline & Total & 144 & 28.46 & 181 & 36.79 & 171 & 34.76 & 553 & 100 & & \\
\hline Received & Yes & 134 & 27.24 & 188 & 38.21 & 170 & 34.55 & 553 & 100 & 9.202 & 0.01 \\
\hline instructions & No & 10 & 16.39 & 18 & 29.51 & 33 & 54.10 & 61 & 100 & & \\
\hline & Total & 144 & 26.04 & 206 & 37.25 & 203 & 36.71 & 553 & 100 & & \\
\hline If yes, in what & Written & 3 & 17.65 & 9 & 52.94 & 5 & 29.41 & 17 & 100 & * & 0.003 \\
\hline form? & Verbal & 33 & 27.73 & 43 & 36.13 & 43 & 36.13 & 119 & 100 & & \\
\hline & Both written and verbal & 98 & 28.24 & 136 & 39.19 & 113 & 32.56 & 347 & 100 & & \\
\hline & Other & 0 & .00 & 0 & .00 & 9 & 100.00 & 9 & 100 & & \\
\hline & Total & 134 & 27.24 & 188 & 38.21 & 170 & 34.55 & 553 & 100 & & \\
\hline Frequency & Once a day & 59 & 26.34 & 98 & 43.75 & 67 & 29.91 & 224 & 100 & 36.531 & 0.001 \\
\hline of brushing & Twice a day & 42 & 28.00 & 65 & 43.33 & 43 & 28.67 & 150 & 100 & & \\
\hline & Three times a day & 31 & 36.90 & 25 & 29.76 & 28 & 33.33 & 84 & 100 & & \\
\hline & Never & 0 & .00 & 0 & .00 & 14 & 100.00 & 14 & 100 & & \\
\hline & Total & 132 & 27.97 & 188 & 39.83 & 152 & 32.20 & 472 & 100 & & \\
\hline Gingival bleeding & Yes & 56 & 23.14 & 86 & 35.54 & 100 & 41.32 & 242 & 100 & 4.223 & 0.121 \\
\hline & No & 88 & 28.30 & 120 & 38.59 & 103 & 33.12 & 311 & 100 & & \\
\hline & Total & 144 & 26.04 & 206 & 37.25 & 203 & 36.71 & 553 & 100 & & \\
\hline Periodontal & Yes & 24 & 24.24 & 37 & 37.37 & 38 & 38.38 & 99 & 100 & 0.242 & 0.886 \\
\hline treatment & No & 120 & 26.43 & 169 & 37.22 & 165 & 36.34 & 454 & 100 & & \\
\hline & Total & 144 & 26.04 & 206 & 37.25 & 203 & 36.71 & 553 & 100 & & \\
\hline Oral hygiene level & Poor & 0 & .00 & 14 & 7.49 & 173 & 92.51 & 187 & 100 & 809.022 & 0.001 \\
\hline & Fair & 11 & 4.80 & 188 & 82.10 & 30 & 13.10 & 229 & 100 & & \\
\hline & Good & 133 & 97.08 & 4 & 2.92 & 0 & .00 & 137 & 100 & & \\
\hline & Total & 144 & 26.04 & 206 & 37.25 & 203 & 36.71 & 553 & 100 & & \\
\hline
\end{tabular}

* Chi square analysis was performed with the help of Monte Carlo Simulation. 
includes the population with low socioeconomic and low education levels. The positive correlation between the prosthesis and oral hygiene indicates that denture cleaning is relevant with the level of knowledge of periodontal care. According to these findings, the level of denture cleaning of participants' RPDs was not sufficiently qualified.

Smoking and its relation with the oral hygiene level have been subjects of many articles. Previous reports in literature support that smoking deteriorates oral hygiene (31). Findings of this study concerning higher percentage of good oral and denture hygiene among non-smokers compared to the smokers are consistent with the outcomes revealed by several previous studies $(31,32)$.

The behavior of the dentists and dental staff is the primary tool guiding the behavior of the geriatric patients. The attitude, body language and communication skills of the dentist are critical to create positive dental visit experience. This study revealed the correlation between the level of cleaning of participants' RPDs and the manner in which patients were advised concerning the care of their denture. $70.53 \%$ of the patients who received both had better denture cleaning in comparison with the patients provided only with verbal instructions. In accordance with the result of previous studies, this result shows the importance of giving detailed information to patients $(17,33-35)$.

Geiballa et al. showed that the majority of dentists did not pay attention to the post treatment instructions concerning the maintenance of fixed prosthesis (36).

It is important to have regular dental visits and follow patients which will allow monitoring of patient oral health. Regular calls maintain good level of cleaning of participants' RPDs (35) due to the fact that updated verbal and written instructions are provided $(28,37)$.

In the geriatric population studied, $33.15 \%$ of the participants wearing their RPDs less than 1 year had good level and $38.59 \%$ had poor level of denture cleaning. $20 \%$ of the participants using RPDs more than 5 years had good level and $39.6 \%$ had poor level of denture cleaning. This study also presented that denture age had adverse effect on level of cleaning of dentures. It was claimed that patients gave more attention to clean their dentures after they were provided with updated instruction. In compliance with the results of previous studies, these results showed that a large number of patients had to be informed about denture cleaning and care $(27,30)$.

This study also revealed significant relationship between overnight denture use and the level of cleaning of dentures $(p<0.05)$. The result of this study showed that subjects wearing their RPDs overnight had poor level of denture cleaning. A previous study reported that wearing partial denture continuously resulted in more plaque accumulation compared to those using the partial denture only during the day (38). Some studies revealed that denture stomatitis was associated with failure to remove denture overnight (23-25). According to the previous studies, the rate of denture stomatitis differed between 15 and $71 \%$, and the prevalence of denture stomatitis had strong relationship with denture hygiene and denture plaque amount $(39,40)$. Furthermore, higher rate of denture stomatitis was found among patients with poor and fair level of denture cleaning compared to the patients with good level of denture cleaning ( $p<0.05)$.
RPDs may increase the risk of caries, damage on periodontium and the amount of stress on natural teeth due to poor oral hygiene, increased plaque and calculus accumulation, and transmission of excessive forces from occlusal surfaces of the frame of RPDs to the periodontal structures. Adverse impacts of the removable partial dentures on the periodontium can be eliminated, if good oral hygiene is maintained. Ideally, partial denture wearers should brush their remaining teeth after every meal by which periodontal health of the remaining dentition can be maintained. On the other hand, RPDs of the patients whom professional tooth cleaning was applied regularly have only minor adverse effects on the periodontium $(19,41)$. Shigeto et al. showed that RPS-wearing patients who received periodic maintenance care 4 times/year were effective to maintain good periodontal conditions (42).

Dula et. al. assessed education, motivation and awareness of the patients during the stage of RPD's construction and concluded that planned prosthetic treatment with an appropriate design and good oral hygiene could reduce the possibility of occurrence of periodontal disease of abutment teeth (43).

This study further revealed that good level of cleaning of denture was maintained among geriatric patients, who brushed their remaining teeth three times a day. In this framework, it can be recommended that periodontal disease should be eliminated before construction of partial dentures, and the natural teeth should be prepared to provide stability and support for the denture.

The oral cavity offers ideal bacteria breeding area and those affected with periodontal disease are exposed to increased risk of potentially fatal bacteria that enter the bloodstream via infected oral tissue. According to the present study, periodontal treatment before prosthetic construction had no effect on the level of denture cleaning. The reason is that geriatric patients may not correct oral hygiene habits depending on the inadequacy of hand skills. In this study, overnight denture wearing condition was considered; whereas, in-water storage of RPD, which affects periodontal health and denture cleaning, was not analyzed. Therefore, it is recommended that further studies should question whether patients keep their RPS within the water. As xerostomia and the type of brushing method have also impact on the oral hygiene and periodontal health, further studies should also take these two factors into consideration within the scope of their examinations in relevant field.

\section{Conclusion}

It could be concluded that the level of cleaning of dentures is associated with giving detailed information to the geriatric patients about how to use their RPDs, type of advice (verbal or written), regular dental visits, good oral hygiene, smoking habits, socioeconomic level, overnight use and denture age. Furthermore clinicians play an important role on maintenance of patient motivation. It is possible to prevent the periodontal diseases by providing detailed information about the oral hygiene habits to the patients and having them maintain adequate oral and denture hygiene. Consequently the clinicians should advice and motivate the patient in RPD maintenance and oral hygiene procedures. 
Further longitudinal studies are needed to better evaluate the effect of periodontal treatment before prosthetic construction in geriatric population.

Türkçe Öz: Hareketli bölümlü protezi olan geriatrik hastalarda oral hijyen alışkanlıkları, periodontal durum ve oral hijyen bilgisi ile protez bakımı arasındaki ilişkinin değerlendirilmesi. Amaç: Bu çalışmanın amacı hareketli parsiyel protez kullanan geriatrik hastalarda oral hijyen alışkanlıkları ve oral hijyen bilgisi ile protez bakımı arasındaki ilişkinin değerlendirilmesidir. Bu çalışma aynı zamanda protez temizliği ile diş fırçalama sıklığı arasındaki ilişkinin değerlendirilmesini de amaçlamaktadır. Hastalar ve yöntem: 65-86 yaşları arasında en az 6 aydır parsiyel protez kullanan toplam 553 hastaya klinik değerlendirmeyi takiben anket yapılmıştır. İstatistiksel değerlendirme için Chi- square analizi ve Fisher's Exact testi kullanılmıştır. Bulgular: Sigara kullanımı sıklığı, protez yaşı, gece protez kullanımı, protez stomatiti ve protez bakımı arasında önemli bir ilişki bulunmuştur $(p<0.05)$. Protez bakımı ile ilgili bilgisi olmadığını belirten hastaların \%54.10'unun protez bakım seviyesi zayıf düzeyde bulunmuştur. Günde 1 defa dişlerini fırçaladıklarını belirten hastaların \%26.34'ünün protez bakım düzeyinin iyi seviyede olduğu bulunurken dişlerini günde 3 defa firçaladığını belirten hastaların \%39.4'ünün de protez bakım düzeyinin iyi seviyede olduğu bulunmuştur. Sonuç: Hastalara verilen bilgilendirmenin ne şekilde olduğunun (yazılı veya sözlü) ve hastaların ağız hijyeni alışkanlıklarının protez bakım düzeyleri üzerine etkisinin sosyoekonomik seviye, sigara kullanımı, gece protez kullanımı, protez yaşı gibi faktörlerden daha önemli olduğu gösterilmiştir. Anahtar Kelimeler: ağız hijyeni; bilgilendirme; geriatri; hareketli bölümlü protez; diş firçalama.

Ethics Committee Approval: The protocol of this study was approved by the Okmeydanı Training and Research Hospital Ethics Committee (No.838). This study was performed in compliance with the Declaration of Helsinki.

Informed Consent: The informed consents were provided by the participants.

Peer-review: Externally peer-reviewed.

Author contributions: ZTC designed the study. AY and PGK participated in generating the data for the study. AY and PGK participated in gathering the data for the study. ZTC participated in the analysis of the data. ZTC wrote the majority of the original draft of the paper. ZTC participated in writing the paper. All authors approved the final version of this paper.

Conflict of Interest: The author had no conflict of interest to declare.

Financial Disclosure: The authors declared that they have received no financial support.

Acknowledgment: We are thankful to Pelin Yıldı/Langpod Translation Services in editing the English version of the article.

\section{References}

1. Günday M, Sener ID, Yamaner G. The study of the age of becoming edentulous in the last 20 years in Turkey. Arch Gerontol Geriatr. 2009;49(1):172-175. [CrossRef]

2. Sussex PV, Thomson WM, Fitzgerald RP. Understanding the 'epidemic' of complete tooth loss among older New Zealanders. Gerodontology 2010;27(2):85-95. [CrossRef]

3. Divaris K, Ntounis A, Marinis A, Polyzois G, Polychronopoulou A. Loss of natural dentition: multi-level effects among a geriatric population. Gerodontology 2012;29(2):e192-e199. [CrossRef]

4. Thomson WM, Ma S. An ageing population poses dental challenges. Singapore Dent J 2014;35C:3-8. [CrossRef]
5. Pellizzer EP, Almeida DA, Falcon-Antenucci RM, et al: Prevalence of removable partial dentures users treated at the Aracatuba Dental School-UNESP. Gerodontology 2012;29:140-4. [CrossRef]

6. Allen PF, Jepson NJ, Doughty J, et al: Attitudes and practice in the provision of removable partial dentures. Br Dent J 2008;204:1-5. [CrossRef]

7. Behr M, Zeman F, Passauer T, et al: Clinical performance of cast clasp-retained removable partial dentures: a retrospective study. Int J Prosthodont 2012;25:138-44.

8. Kassebaum NJ, Bernabe E, Dahiya M, et al: Global burden of severe tooth loss: a systematic review and meta-analysis. J Dent Res 2014;93(7 Suppl):20s-28s. [CrossRef]

9. Marcenes W, Kassebaum NJ, Bernabe E, et al: Global burden oforal conditions in 1990-2010: a systematic analysis. J Dent Res 2013;92:592-7. [CrossRef]

10. Burt BA, Ismail Al, Morrison EC, Beltran ED. Risk factors for tooth loss over a 28-year period. J Dent Res 1990;69(5):1126-30. [CrossRef]

11. Dhingra K. Oral rehabilitation considerations for partially edentulous periodontal patients. J Prosthodont 2012;21:494513. [CrossRef]

12. Tramini P, Montal S, Valcarcel J. Tooth loss and associated factors in long-term institutionalised elderly patients. Gerodontology 2007;24(4):196-203. [CrossRef]

13. Hamasha AA, Sasa I, Al-Qudah M. Risk indicators associated with tooth loss in Jordanian adults. Community Dent Oral Epidemiol 2000;28(1):67-72. [CrossRef]

14. Slade GD, Gansky SA, Spencer AJ. Two-year incidence of tooth loss among South Australians aged 60+years. Community Dent Oral Epidemiol 1997;25(6):429-37. [CrossRef]

15. Vysniauskaité $\mathrm{S}$, Kammona N, Vehkalahti MM. Number of teeth in relation to oral health behaviour in dentate elderly patients in Lithuania. Gerodontology 2005;22(1):44-51. [CrossRef]

16. Esan TA, Olusile AO, Akeredolu PA, Esan AO. Socio-demographic factors and edentulism: the Nigerian experience. BMC Oral Health 2004;4(1):3. [CrossRef]

17. Ribeiro DG, Jorge JH, Varjão FM, Pavarina AC, Garcia PP. Evaluation of partially dentate patients' knowledge about caries and periodontal disease. Gerodontology 2012;29(2):e253-e258. [CrossRef]

18. Vanzeveren C, D'Hoore W, Bercy P, Leloup G. Treatment with removable partial dentures: a longitudinal study. Part II. J Oral Rehabil 2003;30(5):459-69. [CrossRef]

19. Bergman B, Hugoson A, Olsson CO. Caries, periodontal and prosthetic findings in patients with removable partial dentures: a ten-year longitudinal study. J Prosthet Dent 1982;48(5):50614. [CrossRef]

20. Akaltan F, Kaynak D. An evaluation of the e ects of two distal extension removable partial denture designs on tooth stabilization and periodontal health. J Oral Rehabil 2005;32:8239. [CrossRef]

21. Budtz-Jorgensen E, Bertram U. Denture stomatitis. I. The etiology in relation to trauma and infection. Acta Odontol Scand 1970;28(1):71-92. [CrossRef]

22. Jainkittivong A, Aneksuk V, Langlais RP. Oral mucosal lesions in denture wearers. Gerodontology 2010;27(1):26-32. [CrossRef]

23. Baran I, Nalçaci R. Self-reported denture hygiene habits and oral tissue conditions of complete denture wearers. Arch Gerontol Geriatr 2009;49(2):237-41. [CrossRef]

24. Cakan U, Yuzbasioglu $\mathrm{E}$, Kurt $\mathrm{H}$, et al. Assessment of hygiene habits and attitudes among removable partial denture wearers in a university hospital. Niger J Clin Pract 2015;18(4):511-5. [CrossRef]

25. De Castellucci Barbosa L, Ferreira MR, de Carvalho Calabrich CF, Viana AC, de Lemos MC, Lauria RA. Edentulous patients' knowledge of dental hygiene and care of prostheses. Gerodontology 2008;25(2):99-106. [CrossRef]

26. Chowdhary R, Chandraker NK. Clinical survey of denture care in denture-wearing edentulous patients of Indian population. Geriatr Gerontol Int 2011;11(2):191-5. [CrossRef] 
27. Ercalik-Yalcinkaya S, Özcan M. Association between oral mucosal lesions and hygiene habits in a population of removable prosthesis wearers. J Prosthodont 2015;24(4):271-8. [CrossRef]

28. Milward $P$, Katechia D, Morgan MZ. Knowledge of removable partial denture wearers on denture hygiene. $\mathrm{Br}$ Dent $\mathrm{J}$ 2013;215(10):E20. [CrossRef]

29. Peracini A, Andrade IM, Paranhos Hde F, Silva CH, de Souza RF. Behaviors and hygiene habits of complete denture wearers. Braz Dent J 2010;21(3):247-52. [CrossRef]

30. Evren BA, Uludamar A, Işeri U, Ozkan YK. The association between socioeconomic status, oral hygiene practice, denture stomatitis and oral status in elderly people living different residential homes. Arch Gerontol Geriatr 2011;53(3):252-7. [CrossRef]

31. Sreedevi M, Ramesh A, Dwarakanath C. Periodontal status in smokers and nonsmokers: a clinical, microbiological, and histopathological study. Int J Dent 2012;2012:571-590. [CrossRef]

32. Zimmermann $H$, Hagenfeld D, Diercke $K$, et al. Pocket depth and bleeding on probing and their associations with dental, lifestyle, socioeconomic and blood variables: a cross- sectional, multicenter feasibility study of the German National Cohort. BMC Oral Health 2015;21;15:7. [CrossRef]

33. Barreiro DM, Scheid PA, May LG, Unfer B, Braun KO. Evaluation of procedures employed for the maintenance of removable dentures in elderly individuals. Oral Heal Prev Dent 2009;7:243-9.

34. Osmari D, Fraga S, Braun KO, Unfer B. Behaviour of the Elderly with Regard to Hygiene Procedures for and Maintenance of Removable Dentures. Oral Health Prev Dent 2016;14:21-6.

35. Petridis $\mathrm{H}, \mathrm{Hempton} \mathrm{TJ}$. Periodontal considerations in removable partial denture treatment: a review of the literature. Int J Prosthodont 2001;14(2):164-72.
36. Geiballa GH, Abubakr NH, Ibrahim YE. Patients' satisfaction and maintenance of fixed partial denture. Eur J Dent 2016;10:250-3. [CrossRef]

37. Burnett CA, Calwell E, Clifford TJ. Effect of verbal and written education on denture wearing and cleansing habits. Eur J Prosthodont Restor Dent 1993;2(2):79-83.

38. Addy $M$, Bates JF. Plaque accumulation following the wearing of different types of removable partial dentures. J Oral Rehabil 1979;6(2):111-7. [CrossRef]

39. Gendreau L, Loewy ZG. Epidemiology and etiology of denture stomatitis. J Prosthodont 2011;20(4):251-60. [CrossRef]

40. Marchini L, Vieira PC, Bossan TP, Montenegro FL, Cunha VP. Selfreported oral hygiene habits among institutionalised elderly and their relationship to the condition of oral tissues in Taubate, Brazil. Gerodontology 2006;23:33-7. [CrossRef]

41. Isidor F, Budtz-Jørgensen E. Periodontal conditions following treatment with distally extending cantilever bridges or removable partial dentures in elderly patients. A 5-year study. J Periodontol 1990;61(1):21-6. [CrossRef]

42. Koyama S, Hanabuchi S, Fuji T, Ina Y, Yoda N, Hanawa S, et al. The difference between baseline and 5-year examinations at recall in PCR, PD, tooth mobility, and BRL of abutment teeth in subjects who had received periodic maintenance care more than 4 times/year. Ann Jpn Prosthodont Soc 2012;4:59-67. [CrossRef]

43. Dula LJ, Shala KS, Pustina-Krasniqi T, Bicaj T, Ahmedi EF. The infuence of removable partial dentures on the periodontal health of abutment and non-abutment teeth. Eur J Dent 2015;9:382-6. [CrossRef] 